\title{
The Partnership Between Man and Earth
}

\author{
Uliana Alekseevna Vinokurova ${ }^{1,2,3^{*}}$, Elvira Andreevna Alekseeva ${ }^{2}$, Anastasia $^{2}$ \\ Danilovna Alekseeva ${ }^{2}$, Augusta Petrovna Diakonova ${ }^{2}$, Mariya Egorovna Osipova $^{2}$, \\ Daria Nikolaevna Filippova ${ }^{2}$
}

\author{
${ }^{1}$ Circumpolar Civilization Scientific and Research Centre, Arctic State Institute of Culture and Arts, Yakutsk, Russia \\ ${ }^{2}$ Department of Sociology and Human Resources Management, Institute of Finances and Economics, M.K. Ammosov \\ North-Eastern Federal University, Yakutsk, Russia \\ ${ }_{3}$ Churapcha State Institute of Physical Education and Sports, Churapcha, Russia \\ * Corresponding author. Email: uottaah1707@gmail.com
}

\begin{abstract}
The article substantiates the turn to the earth-centric paradigm of man's attitude towards nature as the partnership between Man and Earth, and the changes of conceptual apparatus for studying the ManNature inter-conjugation and co-evolution. It reveals the limits of concepts of "anthropocentrism", "anthropocosmocentrism", "environment", "man is the measure of all things", "nature is the home of man", "self-value of nature".

It is proposed to use P.A.Kropotkin's theory of mutual aid, theories of bioregionalism, organicism, living logic, to introduce the concepts of "planet Earth ecosophy", "Earth rights", "bioregion", "Indigenous Methodology world design" as the basis for the paradigm of the partnership between Man and Earth. Keywords: Ecosophy, ecophobia, Earth rights, Indigenous Methodology, Earth-centricity, bioregionalism, organicism, P.A. Kropotkin, Arctic circumpolar civilization
\end{abstract}

\section{INTRODUCTION}

Global climate change and melting ice are bringing the Arctic Ocean and its flowing rivers of the three continents into civilizational processes. This process is different from the previously known resources of local and world civilizations development: the Earth itself, under changing geo-climatic conditions on the North Pole that has an integral influence on the oecumene of mankind, enters into force. It became inexorably necessary to consider the position of the planet itself as a partner of Man. Such paradigm requires human penetration into the essence of the planet life as a living organism. The article explains the meaning of this paradigm called the Earth ecosophy on partnership between Man and Earth basis.

The Earth is the only man-living place. While selfrecovery in a changing climate, the Earth exposes all living beings to a variety of cataclysms: floods, earthquakes, tsunamis, fires, prolonged droughts, volcanic eruptions, sudden severe frosts, snow, rain, winds, landscape changes, pandemics - all of these risks and threats take millions of lives in an instant. Therefore, we need to find paradigms of co-evolution with the planet.

\section{METHODOLOGY}

In this article we substantiate the methodology of the Man and Earth co-evolution paradigm development from the perspective of Indigenous Methodology position. Following research methodology, a combination of sources was used for data collection: literature review, observations, survey questionnaire.

Mankind faces an inexorably impending task - to find harmonious forms of co-evolution with the natural environment, with the rapidly narrowing space of life of nature. So-called "unexplored wilderness" or rather the wildlife remains only in hard-to-reach places with harsh climatic conditions that limit demographic processes. To that end, it is necessary to reconsider the human-nature relationship and recognize the intrinsic value of the nature as the home of man. At present, these relations have entered a phase of confrontation, on one hand, and, the resources of self-recovery of nature need to be understood and protected by man who makes an evolutionary ecophilic turn in earthman consciousness, on the other. Natural disasters can be perceived in the focus of Indigenous Methodology as the lesson about human attitude towards it. This methodology requires the development of the categorical apparatus reflecting Earth subjectivity. It applies particularly to the erroneous ecophobic concepts such as "environment", "anthropocentrism", "man is the measure of all things", 
"domination over nature", as well as the introduction of new ecophilic concepts, such as "rights of the Earth", "partnership with the Earth", "conscious moral responsibility for the life of the Earth", "creation with the Earth", "equality and justice for the Earth, for wildlife", "living knowledge", "living logic", "planetary approach", "creation of life by man".

The above-mentioned ecophobic terms, generated by man-caused civilization, are anthropocentric, they provide deliberately ecophobic separation of man and the Earth processes, deny the living self-developing essence of the planet, put it in low position compared with man as a "master, king of nature", referring to the planet as "a home" and a source of natural resources, free place to lay down the law. The ecophilia of the changing man consciousness appears to be the guarantee of sustainable co-evolution of man and the planet life.

The phenomenon of communication, inter-connectedness permeates all aspects of the ecosophical partnership. The main conditions for the recognition of the Earth's ecosophy are a partnership with the Earth's Wildlife, following the whole set of ecologically positive worldviews of the Earth's nations, planetary approach to the moral responsibility for the life of the Earth and recognition of the Earth's rights [1]. This interpretation of ecosophy is based on an attitude towards the Earth as an animate, reflective, self-organizing essence peculiar to the worldview of the world's indigenous peoples, which is developed by indigenous scholars in Humanities and Socio-cultural areas. According to indigenous peoples' worldview, partnership with the Earth is founded on the principles of environmental justice that considers the interests of people and the planet. The Earth is a beautiful living-being existing in its primeval ecosophy where mankind does live [2].

Indigenous Methodology ecocentric value claims that nature is a spiritualized essence, common home that establishes equality of all creatures living on earth creatures self-limiting themselves in use of natural resources without destroying ecological niches. These earth-centered values were described in P.Kropotkin, Russian scientist studying indigenous peoples of Siberia, theory of mutual aid, as the value of Kindness, Courage and Generosity. Based on natural life observations of the Buryats, Yakuts, and other indigenous peoples of Asia, Africa, he formulated ethical norms and relations in society and nature, surpassing international laws on nature protection for almost centuries ahead. He argued that mutual assistance is the predominant value of nature and that feelings of mutual assistance, justice and morality are deeply embedded in man with all the strength of instincts [3]. P.Kropotkin's views, based on ecophilic worldview of indigenous peoples, disprove the positions of social Darwinists, who established the foundations of ecophobic industrial civilization.

\section{RESULTS AND DISCUSSIONS}

The shift towards understanding the state of the Earth itself from the perspective of its interests implies the need to develop an earth-centric view of man. Ecophilic indigenous peoples and representatives of ecophobic industrial civilization meetings were often arranged around conflict, the process is perceived as being subject to the protection of traditional habitats. One example is the "Earth First!" movement that aims at protecting nature [4]. Movement activists support indigenous peoples resistance against violation of their rights to ancestral lands, pollution projects.

Forest fires and other natural disasters appear in unequal vulnerability of different social strata. Social factors such as race, gender, ability, and poverty are reflected in the significance of damage caused disasters. Law and the policy that permanently marginalize people and communities in normal times make indigenous communities more vulnerable to natural disasters not of their making [5]. Disaster management experience shows that ecophobic people, not the environment, cause disaster because existing laws are not eco-centric, do not rely on "earth-centric" values, perpetuate environmental racism and environmental injustices, and create a flood of environmental refugees forced to flee their homes under the policy of deterritorialization. The poverty of indigenous peoples who do not want to leave their homes is forcing them to change their ethnocultural values of nature conservation and to feed themselves in ecophobic ways [6]. One such example is the extraction of mammoth bones. Indigenous peoples living in Yakutian Arctic have begun to collect mammoth ivory, although the practice of mammoth and earth untouchability remains a part of their traditional culture. They try to collect it from the surface of the soil, banks, and streams with the assistance of a henchman. So-called "industrial" method of extracting fossil mammoth bones is carried out by washing the soil with a large amount of water under pressure. This technology uses a lot of fuel, it may cause landslides and environmental water pollution, constant noise of the engine scares away fishes, birds, and mammals.

At present, the paleontological materials of mammoth fauna collection, researches, use of it, extracting and trading of it are not fully regulated by the current legislation of the Russian Federation, and environmental values preserving the integrity of the permafrost-saving landscape of indigenous peoples of the North are not taken into consideration.

Ecocentric images of earth and nature suggest that man is the product of nature and society; man is a child of nature. The ecosophical approach is widely implemented at Local Futures, the members of which seek to protect and restore ecological and social well-being by moving away from globalization to glocalization and localization, to revive cultural and biological diversity through the strengthening of local and economic communities. It justifies the principles of rooting in place of residence with pleasure, 
creating a sustainable balance with its resources, natural characteristics and the rhythm of natural community life. The local version of future is based on regional and local identity by place of residence. For example, the Arctic identity is formed by young people studying in universities located in the Arctic territories, who are confident in the optimistic perspective of life in the Arctic. This is confirmed by the results of the questionnaire survey among 441 students of the North-Eastern Federal University (Yakutsk), Northern (Arctic) Federal University (Arkhangelsk) and Murmansk Arctic State University (Murmansk). The results of the survey show that majority of students notes the intergenerational transmission of values and knowledge on Arctic is crucial: "Very important" (25-43\%) and "Important" (38-50\%) options were chosen most. The answers to the question "What do you think is the most realistic scenario for the future of the Russian Arctic in ten years?" showed that half of the students are optimistic. The option "Guarded optimistic: enhancing the quality of life over a long period, demographic growth" was chosen by a third 31$40 \%$ of respondents.

The option "Optimistic: enhancing the quality of life, prosperity of the Arctic territories, growth of population and labor resources, circumpolar cooperation of the countries" was considered as the possible scenario by 20 $24 \%$ of the surveyed students. One-third of NArFU, 13$18 \%$ of NEFU and MASU students are concerned for the future: the option "Stressful: Partial disturbance of Arctic ecology for indigenous peoples living, depletion of natural resources" was chosen by them. A minority of students (4$7 \%)$ is pessimistic. The scenarios for the future of the Arctic present young people worriying about possible environmental degradation of Acrtic that depends on bioregional dynamics.

The problem of balancing the coevolution of man and nature was legally resolved in 1982, when the UN General Assembly adopted the World Charter for Nature, which states that "any form of life is unique and deserves to be respected, no matter how beneficial it may be to man", recognizes that "man can, through his actions or their consequences, modify nature and exhaust its resources, and must, therefore, be fully aware of the urgent need to preserve the balance and quality of nature and natural resources. The Charter calls upon states and people to treat natural resources with care and to manage nature sustainably". There are no regulations on the Earth's right to natural living, self-limitation of its resource consumption and special ecological ethics [7].

Ecological ethics assumes natural environment as an active subject that supports the value of the natural world embodied in artistic forms of art. One of the most interesting thing is ecosophical work of the American writer Gary Snyder [8]. The region and planet are represented in Snyder's work as a creative, artistic agent that determines human features. The result of the development of the ecosophical culture is the priority of family value, social activity, and mutual aid. He rightly believes it is necessary to include a place of own residence in the ethical universe of the human moral code. This requirement does not appear in the World Charter for Nature.

The notion of "bioregion" seems to be very productive in justifying the ecological movement to protect the nature of river basins. A bioregion is a territorial unit that implies ecological and cultural unity, whose boundaries are determined by natural factors and coincide with the boundaries of ecosystems. River basins are, on the one hand, the blood vessels of civilizations, states and peoples and, on the other hand, the reservoirs of life on the planet. The reverence of native rivers is one of the sustainable manifestations of the bioregional strategy and ecocentric picture of the world. The importance of rivers and water resources is increasing in the context of global climate change, transport logistics and strengthening local identity role. The freezing-thawing river periods in cold areas are extremely important for transport infrastructure. The frozen water surface forms a road and provides access to areas that do not have year-round transport links. The winter road provides an opportunity to deliver socially important goods and services to residents of remote and inaccessible areas. It is literally the road of life for people isolated by natural off-road. The problem of roads preparing, logistics - another important aspect of the partnership between man and land.

The economic development of remote and hard-to-reach areas proceeds from the psychology of natural resources consumer, that doesn't consider the degree of damage to the planet. One of the regional environmental disasters is the dam breakthrough of the diamond-mining enterprise ALROSA on August 19, 2018, which led to the pollution of the Vilyuy, Markha, Irelyakh and Malaya Botuobuya rivers in Vilyuysky group of districts of Yakutia. As a result, people living in the bioregion of these rivers were left without fresh water. According to the results of laboratory studies dated August 20, in the water from the dam break, the standards of maximum permissible concentrations for water bodies of fishery purpose were exceeded: suspended solids in 728.6 times, iron in 38.7 times, copper in 27.6 times, at the mouth of the Irelyakh River excess over background concentrations was 689.5 times, iron in 5.4 times, copper in 2.7 times, zinc in 6.1 times. State inspectors of the Ministry of Ecology of Republic Sakha (Yakutia) found pollution in the mouthpart of the Malaya Botuobiya River $170 \mathrm{~km}$ downstream from the site of dam breaks.

The polluted water flow of over $200 \mathrm{~km}$ ran down the Vilyuy River. The ecological disaster was a kind of social experiment for people living in these districts. They formed a public organization supervising work of the government and ALROSA in decontaminating rivers.

The disaster has affected not only four Vilyuysky districts but also the Mirny district, where the company is located. The use of the term "bioregion" makes it possible to unite the efforts of the people from the whole Vilyuy basin in eliminating the consequences of the ecological disaster, 
contributes to the awareness of the Earth's right as an equally affected party.

Thus, bioregionalism becomes the basis for establishing the ecological foundations for human well-being on the planet.

The cultural certainty of existence sets the perspective of the lifeworld [9]. The tendency of underestimation of biological and geoclimatic factors is the result of renaissance anthropocentrism, which opposed culture and nature as two independent spheres. Recognition of earth processes power had led the man of non-technogenic civilizations to different ways of adaptation to living conditions on the planet. Coevolution occurs not only in man but also in animals domesticated by man. For example, Yakut cattle optimally adapted to the way of life in conditions of permafrost and became one of the basic resources of life support for several centuries. In the twentieth century, in pursuit of economic profitability, in these territories were brought meat and dairy cattle, displacing native Yakut cattle. It is now an endangered population. According to the Food and Agriculture Organization of the United Nations (FAO) [10], a species is considered endangered if the total number of fertile female animals is less than or equal to 1000 or the total number of reproducing males is less than or equal to 20 .

The extinction of locally adapted domestic animal species is a global problem. In 2006, FAO compiled a list of 1,311 known livestock species worldwide and reported that 16 percent are already extinct, while another 16 percent are endangered and only 38 percent are out of risk. Today, the threat lies not only in the loss of livestock species but also in the loss of a vast valuable gene pool. If current trends continue, the diversity of livestock species, which has evolved over many millennia, will give way, within a few decades, to small international species of profitable livestock. Interference in natural diversity from human economic interests becomes threatening in scale and disturbing the balance of partnership between man and planet Earth established for thousands of years as a part of the Universe and space order.

In recent years, environmentalism is being formed as a special value of artistic thinking, and art begins to show itself as a life-giving knowledge. The Yakutian films "The Lord Eagle" (2018) and "(The Sun above me never sets)" (2019) became a vivid example of attractiveness and demand for this feature in cinema. They reveal the philosophy of indigenous peoples living in harmony with the natural environment, the attitude of man to the animal world as part of his vital essence. While the western film industry is full of social themes and commercialization, yakutian cinema has come with the bare inner world of a human being living in harmony with the harsh climates. A range of assistance is offered in fiction screenings of works on human stories of indigenous peoples who have survived planetary disasters and assimilated the Earth's ecosophy. The artistic expression of Indigenous Methodology is based on the principle: "The voice of the Earth's ecosophy as an omen will sound even louder and more convincing: Earth first! Earth must be protected together. The Earth closes all elements in one embrace". Therefore, ecosophy is a strategy for the future partnership between man and planet.

\section{CONCLUSION}

The opinion that environmental consciousness can be anthropocentric and ecocentric was established in the scientific literature. The anthropocentric type directly meets the needs of man. Ecocentrism is the optimal response to the needs of both human beings and the natural community as a whole through the partnership between man and the Earth. Its radical expression: Earth First!

The inevitability of meeting of Indigenous Methodology world-design and industrial civilization is particularly evident in the Arctic and its coastal areas. There is a real need to change the whole paradigm of human attitude to life on Earth, in the face of global climate change, the increasing deterioration of people's life quality and all life on the planet Earth because of the pandemic. This challenge to humanity requires an immediate response, primarily from those who has abilities of Living Logic, Living Knowledge, Dialogue and Partnerships.

Environmental wisdom comes from the creative harmonious man communication with the nature, the world of life, symbols of art. Consistency, human coevolution with the environment is understood as the wisdom of ancestors who survived in the given natural conditions. Under this approach, nature becomes an axiological constant of the partnership of civilizations. The ecosophical credo asserts the worldview of the value of primary nature, reasonable creative nature conservation, kindness, beauty of earth life, welfare and security of all living beings, including human beings.

The Ecosophy of the Earth represents a kind of alternative worldview about the values of modern industrial civilization. It is based on the understanding of the planet Earth as a living being and aims to create nature-friendly technologies. In our study, we showed the partnership between Man and the Earth in the ecosophical use of informal roads - winter roads along river beds, in the process of extracting mammoth fauna, preserving adapted breeds of domesticated livestock, and environmental conservation requirements when extracting subsoil resources in the face of climate change in the Arctic territories.

Such features of the Arctic nature as permafrost, extreme cold weather, snow and ice, originality of flora and fauna, tundra landscape, Arctic ocean contribute to the formation of the philosophy as an intuitive intellectual understanding of life on the planet. Extreme environment of the Arctic prevents development of dangerous ideas establishing independence from the environment and geopolitical disunity. 
Global climate change, especially in high latitudes, is bringing to the attention the importance of the Arctic peoples' ecosophy searching strategies for natural and national conservation that can help the Earth to selfsustain a living system. Human interaction with the natural environment and space laws are learned at a visceral intellectual level through the Living Logic of Dialogue and Partnership. An essential principle of the Earth protection is promoting environmental awareness and creating natural sustainability according to its own scenario in future human civilizations.

\section{REFERENCES}

[1] K.I. Shilin, The Earth Charter: a monograph, Ochag, 1997.

[2] U. Vinokurova, Ecosophy: A response to the global climate change, Artes Liberales Lectures 3 (2019) 13-34.

[3] P.A. Kropotkin, Mutual assistance as a factor of evolution, Samoobrazovanie, 2007.

[4] Earth First, Available at:

http://earthfirstjournal.org/.

[5] How Indigenous Leadership is Protecting Communities from Climate Disasters, Earth First (2019), Available at: https://earthfirstjournal.org/newswire/2019/06/19/howindigenous-leadership-is-protecting-communitiesfrom-climate-disasters/.

[6] U. Vinokurova, Indigenous Peoples of Siberia and the Challenges of the Twenty-First Century, Sibirica 17(3) (2018) 3-15.

[7] World Charter for nature, United Nations, Available at: www.un.org/ru/documents/decl_conv/conventions/char ter_for_nature.shtml.

[8] S.V. Grechishkina, The work of Gary Snyder: the formation and development of ecosophical culture in the USA, dissertation of candidate of Sciences, Zabaikalsky state University, 2018.

[9] A.-K.I. Zabulionite, Typological taxon of culture, publishing house of St. Petersburg University, 2009.

[10] G. Signorello, G. Pappalardo, Preliminary results of a survey of farm animal biodiversity conservation actions in Europe under the framework of agenda 2000, in: European Association of Agricultural Economists,
2002 International Congress, August 23-31, 2002, Zaragoza, Spain, Available at: www.ecsocman.hse.ru/data/075/675/1219/sign1.pdf. 